\title{
Psychological Counseling needs and Academic achievement of students at the Secondary level
}

\author{
Sahaya Saila, T. \\ Research Scholar, N.K.T. National College of Education for Women, \\ Triplicane, Chennai-600 005, Tamil Nadu, India \\ Chamundeswari, $\mathbf{S}$. \\ (Corresponding Author) \\ Associate Professor, N.K.T. National College of Education for Women, \\ Triplicane, Chennai-600 005, Tamil Nadu, India \\ E-mail id: rajchamu2006@yahoo.co.in, Mobile: +91 9790953062
}

Accepted: June 01, 2013 Published: June 27, 2013

Doi:10.5296/ijld.v3i3.3923 URL: http://dx.doi.org/10.5296/ijld.v3i3.3923

\begin{abstract}
Psychological counselling that helps to attend to the social emotional needs of the school students which goes a long way in removing obstacles of learning. It is thus, an integral part of education. The present study has investigated the level of psychological counselling needs and academic achievement of students. Survey method was used to carry out the investigation for a sample of students at the secondary level. The study examined the relationship between psychological counselling needs of students and their academic achievement. The sample consisted of 300 secondary school students. Psychological Counselling Needs Scale (Chouhan and Arora, 2009) was used to assess the psychological counselling needs of students and the academic achievement marks scored by students in their half yearly examination were taken. The results of the analyses showed that school psychological counselling needs has significant influence on academic achievement. A significant difference was found between psychological counselling needs and academic achievement of secondary students studying in government, government-aided and private schools. Findings also revealed a significant positive correlation between psychological counselling needs and academic achievement.
\end{abstract}

Keywords: $\quad$ Psychological Counselling Needs, Academic Achievement.

\section{Introduction}

The need for psychological counselling as a practice for promoting adolescent health has been documented worldwide. However, the specific ways by which psychological counselling can be practiced, the optimal settings where psychological counselling can work in the education context, and how successful such programmes are in ensuring gender equity and equality remain largely not discussed in the Asia-Pacific region. Establishing psychological counselling programmes in schools and incorporating gender responsiveness in the context of psychological counselling programmes in secondary education are vital to the achievement of larger education objectives. The term 'school counselling' broadly refers to the process of meeting the needs of students in several areas of development, such as academics, career, and personal. Experts agree that professional school counselling programmes should be 
comprehensive in scope, preventative in design and developmental in nature. The term 'guidance' refers to a more specific trajectory within the field of counselling, a pathway to help students choose a vocational or career path. Guidance is the process of helping people make important choices that affect their lives, such as choosing a preferred life-style. One distinction between guidance and counselling is that while guidance focuses on helping individuals choose what they value most, counselling focuses on helping them make changes.

Early adolescence is a turbulent period. To survive this period, adolescents need guidance and honest assistance. At this stage of life, an adolescent is besieged with multifarious challenges and if these challenges are not resolved, he/ she may become a social misfit. These challenges may adversely affect the academic achievement of adolescents. Education is one of the factors of rating an advance nation and hence the common saying that education is the bedrock of any society. Ironically, school no longer means much to most adolescents as they are so much engrossed with social life. A society whose adolescents are not academically oriented may be classified as under developed. Consequently, adolescents need to be re-integrated academically into their classes and counselling programmes serve as a bridge towards improving academic achievement which in turn will aid in the long run toward national development. There is therefore a need to investigate the relationship between social life adjustment of the adolescent and academic achievement in secondary schools of Chennai city and in this context, the following research questions were raised.

(i) What is the relationship between psychological counselling needs and academic achievement of students at the secondary level?

(ii) To what extent does psychological counselling needs and academic achievement differ among students in different categories of schools?

(iii) Does psychological counselling needs and academic achievement differ between boys and girls at the secondary level?

Thus, the problem is stated as: Psychological Counselling Needs and Academic Achievement of Students at the Secondary Level.

\section{Review of Related Literature}

An exhaustive review is an integral part of research knowledge and fills in the lacunae in available literature. With the above said intention of research, the study has compiled data from empirical literature and utilized the same for extrapolating relevant questions for which answers are not available in the literature collected. The justification for the need and importance of the study thus has been done using the literature. This review collected over a number of years, both in the Western and Indian literature, has been systemically classified and presented with appropriate titles.

\subsection{Academic Achievement}

Academic achievement has become an index of the child's future in this highly competitive world. Academic achievement has been one of the most important goals of the educational process. It is also a major goal, which every individual is expected to perform in all cultures. Academic achievement is a key mechanism through which adolescents learn about their talents, abilities and competencies which are an important part of developing career aspirations. Academic achievement and career aspirations in adolescence are often found to be correlated (Abu-Hilal, 2000). The studies reviewed pertaining to academic achievement are compiled and presented hereunder. 
The qualitative study conducted by Ryan (2007) used data from semi-structured interviews with eight school counselors working with adolescents in secondary education and asked them how they perceived counseling interventions as helping to raise achievement. At a grass root level there is a growing acceptance of having counselors working in schools to support the emotional and psychological needs of children and adolescents. The counselors identified three areas in which they felt their clients' achievement was raised through a counseling intervention: developmentally, socially and less directly, academically. Further study is called for to explore what effect applying a complementary integration and understanding of counseling and educational philosophy might have on raising achievement with adolescents in secondary education.

The aim of the research conducted by Sarfaraz Ahmad (2012) was to study the effect of socio-emotional school environment on academic achievement of teenager-boys. Sample of 250 teenager-boys of higher secondary level were taken at Kanpur city. The results of the study revealed a significant difference in academic achievement of aided and private higher secondary teenager-boys and a significant relation between socio-emotional school environment and academic achievement of teenager-boys. Thus it was concluded that the socio-emotional school environment is one of the important factors that determines the academic achievement of teenager-boys.

\subsection{Psychological Counselling Needs and Academic Achievement}

Psychological counselling is able to help with a broad range of individual and social problems. Many people find it helpful when faced with difficult stages in their normal life cycle such as lowering of academic accomplishments, career changes, loss and bereavement or crisis points in relationships. Others look to psychological counselling to help alleviate distress whether from pressures of living or through longstanding problems which have proved resistant to change. The studies pertaining to psychological counselling needs and academic achievement of students have been compiled and presented hereunder.

The study conducted by Egbochuku (2008) assessed the counselling needs of graduate students within two university ownerships, with the view of striving for better ways of ensuring more effective counselling to clients, which is one of the basic responsibilities of the counsellor. The survey consisted of 636 subjects drawn from two state universities and three federal universities in the South-South zone of Nigeria. It was found that graduates in State Universities had more counselling, educational, vocational and personal-social needs than those in Federal Universities. The findings from the study provided useful information to national policy makers, educational planners, University counsellors, University lecturers and students.

The relationship between vocational self-esteem and psychological needs (autonomy, affiliation, achievement, and dominance) in Turkish counseling students were examined by Civitci (2010). In addition, the moderating effect of gender on the relationship between vocational self-esteem and psychological needs was also investigated. The participants consisted of 281 undergraduate counseling students at Pamukkale University, in Denizli, Turkey. Results of the analysis of the data collected indicated that vocational self-esteem was positively related to need for affiliation and achievement in Turkish counseling students. Vocational self-esteem was higher in female students compared to male students. There was a stronger relationship between vocational self-esteem and need for achievement in females than males.

\section{Hypothesis of the Study}

Based on the research questions and the review the following hypotheses were framed: 
(i) There is a significant relationship between the psychological counseling needs and academic achievement of students in government, government-aided, and private schools at the secondary level.

(ii) There is no significant difference in level of psychological counselling needs among students in government, government-aided, and private schools at the secondary level.

(iii) There is no significant difference in academic achievement among students in government, government-aided, and private schools at the secondary level.

(iv) There is no significant difference in level of psychological counselling needs among boys, girls and co-education students in government, government-aided, and private schools at the secondary level.

(v) There is no significant difference in academic achievement among boys, girls and co-education students in government, government-aided, and private schools at the secondary level.

\section{Research Design}

The investigators took utmost care to establish a sound research methodology, linking psychological and educational variables pertaining to academic achievement. The variables identified have been classified hereunder as independent, dependent and controlled variables.

\subsection{The Variables}

(i) Dependent Variable: Academic Achievement

(ii) Independent Variable: Psychological Counselling Needs

(iv) Controlled Variables: (a) Category of School: Government, Government-aided and Private

(b) Type of School: Boys, Girls and Co-education

Thus the dependent, independent and controlled variables were identified and systematically treated in the present study. The present study has proposed a multivariate research design $3 \times 3$ factorial design expost facto in nature. The design is presented below.

Figure - 1

\section{$3 \times 3$ Factorial Design}

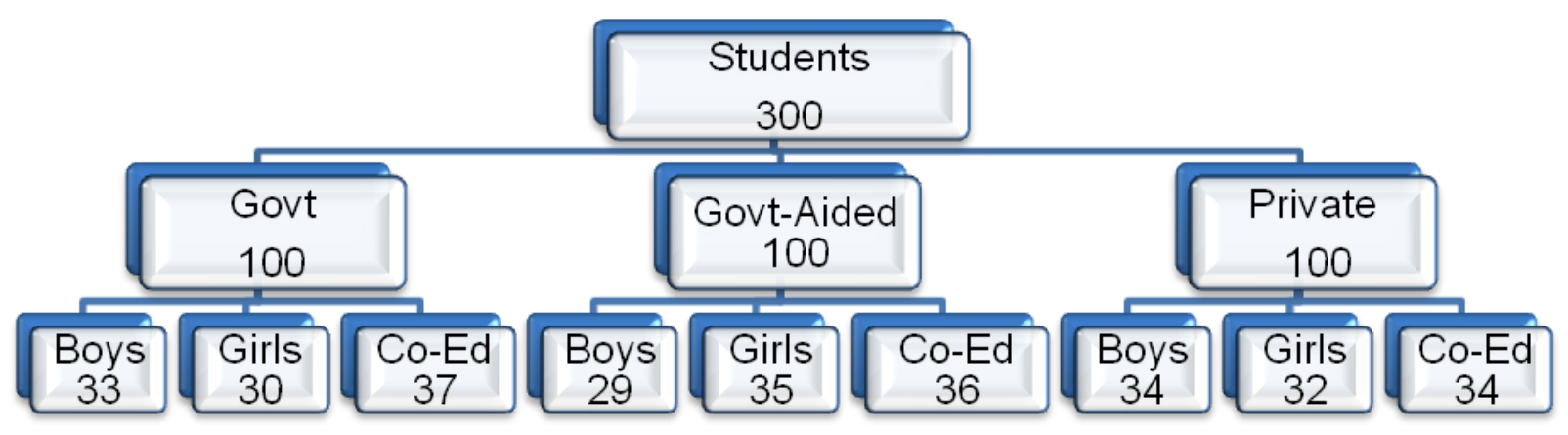

\subsection{Population and Sample Selection}

From the target population of students at the secondary level, a sample of 300 students studying in different categories of schools namely, government, government-aided and private schools was selected at random. 


\subsection{Measures}

\subsubsection{Academic Achievement}

The academic achievement marks scored by students in their half yearly examination was taken.

\subsubsection{Psychological Counselling Needs Scale (Chouhan and Arora, 2009]}

The Psychological Counselling Needs Scale consists of 25 statements with 21 positive items $(1,3,4,5,6,7,8,10,11,13,14,15,16,17,18,19,21,22,23,24,25)$ and 4 negative items $(2,9,12,20)$ on a Five Point Likert Scale.

The reliability of the test calculated for the entire length of the scale on a sample of 100 adolescent boys and girls, aged 13 - 18 years was found to be 0.90 . The validity of the research tool was calculated by the product moment method and was found to be 0.82 . The scores ranged from 25 to 125 .

\section{Results and Discussion}

Secondary school students are unique with facing different challenges in their schools. A rich body of research demonstrates that students are impacted by numerous social, psychological, and environmental factors (Coleman and others, 1966; Griffin and Steen, 2011), and that the current policies in place do not adequately attend to the complex issues that some students must face on a daily basis (Teale and Scott, 2010). Some of these issues include poverty, family distress, violence, and other conditions outside of schools that affect student achievement (Couillard and others, 2006; Flowers and Flowers, 2008).

Responding to student needs by only focusing on improving schools does not guarantee the drastic changes necessary to enhance student educational outcomes (Noguera, 2003). A growing body of research highlights the necessity of schools to address the relationship between the academic challenges students face, and factors related to racial and cultural background and socioeconomic status (Noguera, 2008).

In the present investigation of psychological counselling needs and academic achievement of students in different categories of schools, namely government, government-aided and private schools at the secondary level, a significant positive correlation was found between psychological counselling needs and academic achievement of students at the secondary level (Tables-1a, 1b \& 1c).

Further, a significance difference in psychological counselling needs and academic achievement was observed among students at the secondary level in different categories of schools (Table-2a \& Table-3a). The students in government schools were found to be significantly higher in their psychological counseling needs when compared to the students in other two categories of schools, government-aided and private schools (Table-2b). But looking into their academic achievement the students in private schools are found to be significantly better when compared to their counterparts in other two categories of schools (Table-3b). The students in private schools, hail from a relatively higher socio-economic status, with well educated parents and adequate facilities at home thereby having a conducive learning environment. Looking into the schools, the private schools have committed teachers, with good learning resources, and special facilities, taking care of all the educational and psychological needs of the students. In the case of students in government and government-aided schools, they hail from a relatively lower socio-economic status, parents not very well educated and with an indifferent attitude towards studies. As a result they are able to provide inadequate learning facilities and less support from parents at home. The government and government-aided schools, governed by the Tamil Nadu State Government, have inadequate 
infrastructural facilities, poorly maintained learning resource centers and teaching methodologies not matching with the present day technology advancement. The students in these schools undergo a lot of stress, both at home and school and are psychologically disturbed and are not able to perform academically in comparison to the students in private schools. Thus the students in private schools who do not require much psychological counseling are able to perform academically better when compared to the students in government and government-aided schools.

On comparing the different types of schools, namely, boys, girls and co-education schools with respect to psychological counseling needs in government, government-aided and private schools, it is seen that in government and private schools, the psychological counseling needs of students in girls' schools are significantly higher than the students in boys and co-education schools (Tables-4a \& b; 6a \& b). Usually the students in girls' schools are usually brought up in a very secluded environment, with very less exposure to the outside world. As a result the psychological needs of the students in girls' schools are much higher than the psychological needs of students in other two types of schools. But surprisingly, in the case of government-aided schools, on comparing the counseling needs of students in different types of schools, the students in boys' schools are found to be higher and students in co-education schools lower in their counseling needs (Table-5a \& b).

Though the students in girls' schools belonging to government and private schools are significantly higher in psychological counseling needs, they are found to perform better academically when compared to the students in boys and co-education schools (Table-7a \& b; $9 \mathrm{a} \& \mathrm{~b})$. The students in girls' schools grow up with more concentration and care both in school and home and as result with no distraction are able to perform academically better inspite of higher psychological counseling needs. In the case of government-aided schools, the students in co-education schools who were very less in their counseling needs were found to perform academically better when compared to the students in girls and boys schools.

\section{Suggestions for further Research}

Research in the area of psychological counselling needs and academic achievement can be extended to all levels of school students, a comparison can made between different levels of students and also among the urban and rural children.

\section{Conclusion}

From the present study, it was found that counselling needs of students are not always dependent on the personnel who may be providing the intervention. In order to provide effective support, remove obstacles, and make students successful in school, students' perceptions of their needs must be investigated. The survey must be carried out carefully and logically, covering each possible aspect of the middle school student's life. Furthermore, the results of the survey must be considered within the context of each student's life and as a result, interventions will be more appropriate and meaningful to the student. This will foster success for the student and ultimately the school. The research conducted on the outcomes of school counselling suggests that an effective and comprehensive school guidance program that is fully integrated with the mission of the school and supported by the school administration will help in the success of the students and thereby the school.

The evidence linking school counselling with positive student outcomes in academics, career and personal/social domains appears to be clearly supported through both quantitative and qualitative research. Counselling programmes are further expected to have a positive impact on the areas of academic achievement of students; transitions from middle school level 
to high school level; academic course selection, college and career planning by secondary and high school students; school climate including improvement in classroom behaviour, reduction in discipline problems, fostering a greater sense of belonging among students and improved school safety due to a reduction in violence; reduction in drop-out rates through efforts to keep students in school.

\section{REFERENCE}

Abu-Hillal, M.M. (2000). A Structural Model of Attitudes toward School Subjects, Academic Aspiration and Achievement. Educational Psychology, 20, 75-84.

Chouhan, V.L. and Arora, G.G. (2009). Psychological Counselling Needs Scale, Ahmedabad.

Civitic, A. (2010). Vocational Self-esteem and Psychological Needs in Turkish Counselling Students. International Journal for the Advancement of Counselling, 32(1), 56-65.

Coleman, J.S., Campbell, E.Q., Hobson, C.J., McPartland, J., Mood, A. M., Weinfeld, F.D., and York, R.L. (1966). Equality of Educational Opportunity. Washington, D.C. Government Printing Office.

Couillard, D., Garnett, J., Hutchins, A., Fawcett, M., and Maycock, G. (2006). Student Risk Factors Identified By School Counsellors and Student Achievement. Alberta Journal of Educational Research, 52, 277-288.

Egbochuku, E.O. (2008). Guidance and Counselling: A Comprehensive Test, UNIBEN Press, Nigeria.

Flowers, T.A., and Flowers, L.A. (2008). Factors Affecting Urban African American High School Students' Achievement in Reading. Urban Education, 43(2), 154-171.

Griffin, D. and Steen, S. (2010). School-Family-Community Partnerships: Applying Epstein's Theory of the Six Types of Involvement to School Counsellor Practice. Professional School Counselling, 13, pp. 218-226.

Griffin, D. And Steen, S. (2011). A Social Justice Approach to School Counseling. Journal for Social Action in Counselling and Psychology, 3(1), 74-84.

Noguera, P.A. (2003). City Schools and the American Dream: Reclaiming the Promise of Public Education. New York: Teachers College Press.

Ryan, J.A. (2007). Raising Achievement with Adolescents in Secondary Education-School Counsellors Perspective. British Education Journal, 33(4), 551-563.

Sarfaraz Ahmad (2012) International Journal of Scientific and Research Publications, 2(7), ISSN 2250-3153.

Teale, W.H. and Scott, J.L. (2010). Making Urban Schools Better Places for Students, Teachers, and Families: An Interview with Charles Payne. The Reading Teacher, 63, 701-704. 


\section{APPENDIX}

Table-1a: Simple Correlation Matrix between Psychological Counselling Needs and Academic Achievement of Students in Boys, Girls and Co-education Government Schools at the Secondary Level

\begin{tabular}{|l|c|c|}
\hline \multicolumn{1}{|c|}{ Variables } & $\begin{array}{c}\text { Psychological Counselling } \\
\text { Needs }\end{array}$ & Academic Achievement \\
\hline $\begin{array}{l}\text { Psychological Counselling } \\
\text { Needs }\end{array}$ & 1 & $0.45^{* *}$ \\
\hline Academic Achievement & $\mathrm{X}$ & 1 \\
\hline
\end{tabular}

**Significant at 0.01 level

Table-1b: Simple Correlation Matrix between Psychological Counselling Needs and Academic Achievement of Students in Boys, Girls and Co-Education Government-aided Schools at the Secondary Level

\begin{tabular}{|l|c|c|}
\hline \multicolumn{1}{|c|}{ Variables } & $\begin{array}{c}\text { Psychological Counselling } \\
\text { Needs }\end{array}$ & Academic Achievement \\
\hline $\begin{array}{l}\text { Psychological Counselling } \\
\text { Needs }\end{array}$ & 1 & $0.66^{* *}$ \\
\hline Academic Achievement & $\mathrm{X}$ & 1 \\
\hline
\end{tabular}

**Significant at 0.01

Table-1c: Simple Correlation Matrix between Psychological Counselling Needs and Academic Achievement of Students in Boys, Girls and Co-education Private Schools at the Secondary Level

\begin{tabular}{|l|c|c|}
\hline \multicolumn{1}{|c|}{ Variables } & $\begin{array}{c}\text { Psychological Counselling } \\
\text { Needs }\end{array}$ & Academic Achievement \\
\hline $\begin{array}{l}\text { Psychological Counselling } \\
\text { Needs }\end{array}$ & 1 & $0.29^{* *}$ \\
\hline Academic Achievement & $\mathrm{X}$ & 1 \\
\hline
\end{tabular}

**Significant at 0.01 
Table-2a: Analysis of Variance of Psychological Counselling Needs of Students in Different Categories of Schools at the Secondary Level

\begin{tabular}{|l|c|c|c|c|}
\hline Source of Variation & Df & Sum of Square & $\begin{array}{c}\text { Mean of Sum of } \\
\text { Square }\end{array}$ & \multirow{2}{*}{ F-ratio } \\
\hline Between groups & 2 & 97982.34 & 48991.17 & \multirow{2}{*}{$330.866^{* *}$} \\
\cline { 1 - 4 } Within groups & 297 & 43976.63 & 148.07 & \\
\cline { 1 - 3 } \multicolumn{1}{c|}{ Total } & 299 & 141958.97 & - & \\
\hline
\end{tabular}

**Significant at 0.01 level

Table-2b: Statistical Analysis of Psychological Counselling Needs of Students in Government, Government-aided and Private Schools at the Secondary Level

\begin{tabular}{|c|c|c|c|c|c|c|}
\hline Variable & $\begin{array}{c}\text { Sample } \\
\text { Size }\end{array}$ & Mean & SD & SEM & SED & $\mathbf{C R}$ \\
\hline Government & 100 & 88.85 & 11.84 & 1.18 & \multirow{2}{*}{1.49} & \multirow{2}{*}{$5.78 * *$} \\
\hline Government-aided & 100 & 80.24 & 9.06 & 0.91 & & \\
\hline Government & 100 & 88.85 & 11.84 & 1.18 & \multirow{2}{*}{1.90} & \multirow{2}{*}{$22.02 * *$} \\
\hline Private & 100 & 46.94 & 14.90 & 1.49 & & \\
\hline Government-aided & 100 & 80.24 & 9.06 & 0.91 & \multirow{2}{*}{1.74} & \multirow{2}{*}{$19.10 * *$} \\
\hline Private & 100 & 46.94 & 14.90 & 1.49 & & \\
\hline
\end{tabular}

**Significant at 0.01 level

Table-3a: Analysis of Variance of Academic Achievement of Students in Different Categories of Schools at the Secondary Level

\begin{tabular}{|l|c|c|c|c|}
\hline Source of Variation & Df & Sum of Square & $\begin{array}{c}\text { Mean of Sum of } \\
\text { Square }\end{array}$ & \multirow{2}{*}{ F-ratio } \\
\cline { 1 - 3 } Between groups & 2 & 2373617.22 & 1186808.61 & \\
\cline { 1 - 3 } Within groups & 297 & 830611.03 & 2796.67 & \multirow{2}{*}{$424.37 * *$} \\
\cline { 1 - 3 } Total & 299 & 3204228.25 & - & \\
\hline
\end{tabular}

**Significant at 0.01 level 
Table-3b: Statistical Analysis of Academic Achievement of Students in Government, Government-aided and Private Schools at the Secondary Level

\begin{tabular}{|c|c|c|c|c|c|c|}
\hline Variable & $\mathbf{N}$ & Mean & S.D & SEM & SED & CR \\
\hline Government & 100 & 211.36 & 53.84 & 5.38 & \multirow[t]{2}{*}{8.17} & \multirow{2}{*}{$3.83 * *$} \\
\hline Government-aided & 100 & 242.65 & 61.49 & 6.15 & & \\
\hline Government & 100 & 211.36 & 53.84 & 5.38 & \multirow[t]{2}{*}{6.79} & \multirow{2}{*}{$29.81 * *$} \\
\hline Private & 100 & 413.74 & 41.365 & 4.14 & & \\
\hline Government-aided & 100 & 242.65 & 61.49 & 6.15 & \multirow[t]{2}{*}{7.41} & \multirow{2}{*}{$23.09 * *$} \\
\hline Private & 100 & 413.74 & 41.37 & 4.14 & & \\
\hline
\end{tabular}

**Significant at $\mathbf{0 . 0 1}$

Table-4a: Analysis of Variance of Psychological Counselling Needs of Students in Boys, Girls and Co-education Government Schools at the Secondary Level

\begin{tabular}{|l|c|c|c|c|}
\hline Source of Variation & Df & Sum of Square & $\begin{array}{c}\text { Mean of Sum of } \\
\text { Square }\end{array}$ & F-ratio \\
\hline Between groups & 2 & 1486.72 & 743.36 & \\
\cline { 1 - 4 } Within groups & 97 & 12394.03 & 127.77 & \multirow{2}{*}{$5.82 * *$} \\
\hline \multicolumn{1}{|c|}{ Total } & 99 & 13880.75 & - & \\
\hline
\end{tabular}

**Significant at 0.01

Table-4b: Statistical Analysis of Psychological Counselling Needs of Students in Boys, Girls and Co-education Government Schools at the Secondary Level

\begin{tabular}{|c|c|c|c|c|c|c|}
\hline Variable & $\mathbf{N}$ & Mean & S.D & SEM & SED & CR \\
\hline Boys & 33 & 91.15 & 9.74 & 1.70 & \multirow{2}{*}{3.36} & \multirow{2}{*}{$0.39^{\mathrm{NS}}$} \\
\hline Girls & 30 & 92.47 & 16.35 & 2.99 & & \\
\hline Boys & 33 & 91.15 & 9.74 & 1.70 & \multirow{2}{*}{1.98} & \multirow{2}{*}{$3.68 * *$} \\
\hline Co-education & 37 & 83.86 & 6.68 & 1.10 & & \\
\hline Girls & 30 & 92.47 & 16.35 & 2.99 & \multirow{2}{*}{2.95} & \multirow{2}{*}{$2.92 *$} \\
\hline Co-education & 37 & 83.86 & 6.68 & 1.10 & & \\
\hline
\end{tabular}

NS - not significant

**Significant at 0.01 level

*Significant at 0.05 level 
Table-5a: Analysis of Variance of Psychological Counselling Needs of Students in Boys, Girls and Co-education Government-aided Schools at the Secondary Level

\begin{tabular}{|l|c|c|c|c|}
\hline Source of Variation & df & Sum of Square & $\begin{array}{c}\text { Mean of Sum of } \\
\text { Square }\end{array}$ & F-ratio \\
\hline Between groups & 2 & 2781.18 & 1390.59 & \\
\cline { 1 - 3 } Within groups & 97 & 5341.06 & 55.06 & \multirow{2}{*}{$25.26^{* *}$} \\
\cline { 1 - 4 } Total & 99 & 8122.24 & - & \\
\hline
\end{tabular}

**Significant at $\mathbf{0 . 0 1}$

Table-5b: Statistical Analysis of Psychological Counselling Needs of Students in Boys, Girls and Co-education Government-aided Schools at the Secondary Level

\begin{tabular}{|c|c|c|c|c|c|c|}
\hline Variable & $\mathbf{N}$ & Mean & SD & SEM & SED & CR \\
\hline Boys & 29 & 85.83 & 8.17 & 1.52 & \multirow{2}{*}{2.05} & \multirow{2}{*}{$1.56^{\mathrm{NS}}$} \\
\hline Girls & 35 & 82.63 & 8.16 & 1.38 & & \\
\hline Boys & 29 & 85.83 & 8.17 & 1.52 & \multirow{2}{*}{1.74} & \multirow{2}{*}{$7.12 * *$} \\
\hline Co-education & 36 & 73.42 & 5.88 & 0.98 & & \\
\hline Girls & 35 & 82.63 & 8.16 & 1.38 & \multirow{2}{*}{1.68} & \multirow{2}{*}{$5.47 * *$} \\
\hline Co-education & 36 & 73.42 & 5.88 & 0.98 & & \\
\hline
\end{tabular}

NS-Not Significant

**Significant at 0.01 level

Table-6a: Analysis of Variance of Psychological Counselling Needs of Students in Boys, Girls and Co-education Private Schools at the Secondary Level

\begin{tabular}{|c|c|c|c|c|}
\hline Source of Variation & Df & Sum of Square & $\begin{array}{c}\text { Mean of Sum of } \\
\text { Square }\end{array}$ & \multirow{2}{*}{ F-ratio } \\
\hline Between groups & 2 & 10883.57 & 5441.78 & \\
\cline { 1 - 4 } Within groups & 97 & 11090.07 & 114.33 & \multirow{2}{*}{$47.60 * *$} \\
\cline { 1 - 3 } Total & 99 & 21973.64 & - & \\
\hline
\end{tabular}

**Significant at 0.01 level 
Table-6b: Statistical Analysis of Psychological Counselling Needs of Students in Boys, Girls and Co-education Private Schools at the Secondary Level

\begin{tabular}{|c|c|c|c|c|c|c|}
\hline Variable & $\mathbf{N}$ & Mean & SD & SEM & SED & CR \\
\hline Boys & 34 & 53.53 & 11.10 & 1.90 & \multirow{2}{*}{2.80} & \multirow{2}{*}{$0.65^{\mathrm{NS}}$} \\
\hline Girls & 32 & 55.34 & 11.63 & 2.06 & & \\
\hline Boys & 34 & 53.53 & 11.10 & 1.90 & \multirow{2}{*}{2.48} & \multirow{2}{*}{$8.51 * *$} \\
\hline Co-education & 34 & 32.44 & 9.26 & 1.59 & & \\
\hline Girls & 32 & 55.34 & 11.63 & 2.06 & \multirow{2}{*}{2.58} & \multirow{2}{*}{$8.88 * *$} \\
\hline Co-education & 34 & 32.44 & 9.26 & 1.59 & & \\
\hline
\end{tabular}

NS - not significant

**Significant at 0.01 level

Table-7a: Analysis of Variance of Academic Achievement of Students in Boys, Girls and Co-education Government Schools at the Secondary Level

\begin{tabular}{|l|c|c|c|c|}
\hline Source of Variation & df & Sum of Square & $\begin{array}{c}\text { Mean of Sum of } \\
\text { Square }\end{array}$ & \multirow{2}{*}{ F-ratio } \\
\cline { 1 - 3 } Between groups & 2 & 19744.28 & 9872.14 & \multirow{2}{*}{$3.58^{* *}$} \\
\cline { 1 - 3 } Within groups & 97 & 267190.76 & 2754.54 & \\
\hline \multicolumn{1}{|c|}{ Total } & 99 & 286935.04 & - & \\
\hline
\end{tabular}

***Significant at 0.01 level

Table-7b: Statistical Analysis of Academic Achievement of Students in Boys, Girls and Co-education Government Schools at the Secondary Level

\begin{tabular}{|c|c|c|c|c|c|c|}
\hline Variable & $\mathbf{N}$ & Mean & SD & SEM & SED & CR \\
\hline Boys & 33 & 192.33 & 44.45 & 7.74 & \multirow{2}{*}{13.84} & \multirow{2}{*}{$2.48 * *$} \\
\hline Girls & 30 & 226.67 & 64.44 & 11.77 & & \\
\hline Boys & 33 & 192.33 & 44.45 & 7.74 & \multirow{2}{*}{11.12} & \multirow{2}{*}{$2.12 * *$} \\
\hline Co-education & 37 & 215.92 & 48.17 & 7.92 & & \\
\hline Girls & 30 & 226.67 & 64.44 & 11.77 & \multirow{2}{*}{13.76} & \multirow{2}{*}{$0.78^{\mathrm{NS}}$} \\
\hline Co-education & 37 & 215.92 & 48.17 & 7.92 & & \\
\hline
\end{tabular}

NS - not significant

***Significant at 0.01 
Table - 8a: Analysis of Variance of Academic Achievement of Students ion Boys, Girls and Co-education Government-aided Schools at the Secondary Level

\begin{tabular}{|l|c|c|c|c|}
\hline Source of Variation & df & Sum of Square & $\begin{array}{c}\text { Mean of Sum of } \\
\text { Square }\end{array}$ & \multirow{2}{*}{ F-ratio } \\
\hline Between groups & 2 & 117478.80 & 58739.40 & \\
\cline { 1 - 3 } Within groups & 97 & 256799.95 & 2647.42 & \multirow{2}{*}{$22.19 * *$} \\
\cline { 1 - 4 } Total & 99 & 374278.75 & - & \\
\hline
\end{tabular}

**Significant at $\mathbf{0 . 0 1}$

Table-8b: Statistical Analysis of Academic Achievement of Students in Boys, Girls and Co-education Government-aided Schools at the Secondary Level

\begin{tabular}{|c|c|c|c|c|c|c|}
\hline Variable & $\mathbf{N}$ & Mean & SD & SEM & SED & CR \\
\hline Boys & 29 & 204.17 & 50.44 & 9.37 & \multirow{2}{*}{12.84} & \multirow{2}{*}{$1.98^{\mathrm{NS}}$} \\
\hline Girls & 35 & 229.63 & 51.68 & 8.74 & & \\
\hline Boys & 29 & 204.17 & 50.44 & 9.37 & \multirow{2}{*}{12.81} & \multirow{2}{*}{$6.44 * *$} \\
\hline Co-education & 36 & 286.31 & 52.03 & 8.67 & & \\
\hline Girls & 35 & 229.63 & 51.68 & 8.74 & \multirow{2}{*}{12.31} & \multirow{2}{*}{$4.60 * *$} \\
\hline Co-education & 36 & 286.31 & 52.03 & 8.67 & & \\
\hline
\end{tabular}

NS-Not Significant

**Significant at 0.01

Table-9a: Analysis of Variance of Academic Achievement of Students in Boys, Girls and Co-education Private Schools at the Secondary Level

\begin{tabular}{|l|c|c|c|c|}
\hline Source of Variation & Df & Sum of Square & $\begin{array}{c}\text { Mean of Sum of } \\
\text { Square }\end{array}$ & \multirow{2}{*}{ F-ratio } \\
\cline { 1 - 4 } Between groups & 2 & 5957.07 & 2978.54 & \multirow{2}{*}{$1.77 *$} \\
\cline { 1 - 4 } Within groups & 97 & 163440.17 & 1684.95 & \\
\cline { 1 - 4 } Total & 99 & 169397.24 & - & \\
\hline
\end{tabular}

*Significant at 0.05 level 
Table - 9b: Statistical Analysis of Academic Achievement of Students in Boys, Girls and Co-education Private Schools at the Secondary Level

\begin{tabular}{|c|c|c|c|c|c|c|}
\hline Variable & $\mathbf{N}$ & Mean & SD & SEM & SED & $\mathbf{C R}$ \\
\hline Boys & 34 & 406.09 & 45.16 & 7.75 & \multirow{2}{*}{11.05} & \multirow{2}{*}{$1.67^{\mathrm{NS}}$} \\
\hline Girls & 32 & 424.56 & 44.58 & 7.88 & & \\
\hline Boys & 34 & 406.09 & 45.16 & 7.75 & \multirow{2}{*}{9.53} & \multirow{2}{*}{$0.54^{\mathrm{NS}}$} \\
\hline Co-education & 34 & 411.21 & 32.35 & 5.55 & & \\
\hline Girls & 32 & 424.56 & 44.58 & 7.88 & \multirow{2}{*}{9.55} & \multirow{2}{*}{$1.39^{\mathrm{NS}}$} \\
\hline Co-education & 34 & 411.21 & 32.35 & 5.55 & & \\
\hline
\end{tabular}

NS - not significant 